\title{
RESTAURANT CUSTOMER SATISFACTION AND RETURN PATRONAGE IN A BLOEMFONTEIN SHOPPING MALL
}

\section{Hermanus Johannes Moolman: Department of Mercantile Law, University of the Free State}

\begin{abstract}
Purpose: Restaurants form one of the core components of a mall's retail offering and its tenant mix. In order to successfully manage the tenant mix, research suggests that mall management continuously monitor their tenants' performance through customer satisfaction and return patronage surveys. The purpose of the study on which this article is based, was to gain insight into restaurant customers' satisfaction and return patronage in a shopping mall context.
\end{abstract}

Research questions: The research was conceptualised with the following three research questions in mind: Which dining attributes are important for customer satisfaction and return patronage in mall restaurants? Is there a difference in restaurant customers' satisfaction and return patronage levels based on their demographic characteristics? Is there a difference in restaurant customers' satisfaction and return patronage in the respective mall restaurants?

Design/methodology/approach: A mixed-methods research design was followed. The views of restaurateurs and mall managers were explored (qualitative) and 590 customers of eight restaurants situated in the mall successfully completed questionnaires (quantitative). Analysis of variance, t-tests, correlation analysis and regression analysis were performed to reach the objectives of the study.

Findings: This research showed that food quality, quality service, restaurant ambience, the quality of facilities and the presence of management are important attributes in contributing to customers' overall dining satisfaction. Food quality and overall dining satisfaction are regarded as important attributes for restaurant customers' decision to return to a mall restaurant. Demographic characteristics of restaurant customers have little impact on customer satisfaction and return patronage levels. Mall restaurants were not equally successful in satisfying their customers in terms of service quality, quality of facilities and the presence of management.

Implications: From a managerial perspective, it is important for mall restaurateurs to continuously strive to increase the levels of customer satisfaction and return patronage by emphasising the dining attributes identified in this article. Mall management needs to monitor customers' satisfaction in those restaurants that obtained significantly lower customer satisfaction ratings. Restaurateurs should address areas identified for improvement by this research.

Originality/value: This article offers the South African restaurant subsector increased insight into customers' satisfaction and return patronage. The contribution of this article is unique in that, for the first time, customer satisfaction and return patronage are investigated from the context of restaurants situated in the same mall. The research findings supported the strategic responsible growth objectives of the National Tourism Sector Strategy.

Keywords and phrases: Mall restaurant, customer satisfaction, customer return patronage, food quality, service quality, ambience, quality of facilities, management presence.

\section{INTRODUCTION}

"South African shopping malls are a retail force to be reckoned with" (South African Tourism, 2010). Malls do not only provide exciting retail experiences and retail therapy for shoppers, but also offer recreational and entertainment opportunities to visitors. This holistic approach to shopping is also evident in the international context. De Nisco and Napolitano (2006:145-146) state that restaurants, in combination with cinemas, exhibitions and live performances, offer mall visitors important recreational and entertainment opportunities in a weatherproof and safe environment. It has therefore become common practice to add restaurants as one of the core components of a mall's retail offering and its tenant mix (Anselmsson, 2006:135). 
Managing a mall and its tenant mix can be seen as a complex and challenging task. As part of its core business, mall management should ensure that the mall provides retail letting space for a profit. Mall managers should furthermore ensure that a supporting function is provided to all its tenants (Pitt \& Musa, 2009:40). In order to manage the tenant mix, mall management is advised to monitor their tenants' performance continuously (Pitt \& Musa, 2009:53). Return patronage (Lotz, Eastlick, Mishra \& Shim, 2010:402) and customer satisfaction are often used as performance indicators to measure success in a mall setting, since these constructs are assumed to play a critical role in the financial sustainability of the mall and its tenants (Anselmsson, 2006:115-116).

Research confirms the strategic importance of customer satisfaction to restaurants. Satisfied customers have a direct impact on restaurants' financial performance (Bernhardt, Donthu \& Kennett, 2000:168; Barsky \& Nash, 2003:173; Chi \& Gursoy, 2009:251), long-term survival (Soriano, 2002:1065; Iglesias \& Guillén, 2004:377; Chi \& Gursoy, 2009:245), and positive word-of-mouth communications (Andaleeb \& Conway, 2006:4; Ladhari, Brun \& Morales, 2008:571). Restaurant customer satisfaction is regarded by many researchers (Ganesh, Arnold \& Reynolds, 2000:66; Soriano, 2002:1057; Susskind, 2002:84; Barsky \& Nash, 2003:173; Cheng, 2005:99; Söderlund \& Öhman, 2005:169; Gupta, McLaughlin \& Gomez, 2007:293; Han, Back \& Barrett, 2009:563) as the antecedent to customers' return patronage. It is estimated that more than ninety per cent of dissatisfied restaurant customers do not return to the same restaurant (Stevens, Knutson \& Patton, 1995) and complain to approximately ten people about poor quality of service (Chung \& Hoffmann, 1998). Although an overwhelming number of research confirms a positive relationship between customer satisfaction and return patronage (Han et al., 2009:570), some researchers (Skogland \& Siguaw, 2004:227; Chow, Lau, Lo, Sha \& Yun, 2007:705-706) found a weak link between the two variables.

This article offers the South African restaurant subsector increased insight into customers' satisfaction and return patronage. In spite of the growing international interest in restaurant customer satisfaction and return patronage research, limited research has been completed on this topic in South Africa. International studies on customers' satisfaction and return patronage might not be applicable to the South African restaurant subsector, since researchers such as Mueller, Palmer, Mack and McMullan (2003:400-403) and Jensen and Hansen (2007:606) suggest that national culture has an effect on research and on restaurant customer satisfaction. The findings of research on restaurant customer satisfaction should therefore be interpreted in the light of its national culture and should not be generalised to other cultures.

The contribution of the research on which this article reports is unique in that, for the first time, customer satisfaction and return patronage were investigated from the context of restaurants situated in the same mall. As far as can be ascertained, there is no further international or national research on restaurant customer satisfaction and return patronage in a mall context. Anselmsson (2006:119) also reports that no research has so far been done about the performance of restaurants and cafeterias in shopping malls. Given the challenge of mall management and the importance of customer satisfaction, research within this context is necessary.

The article provides a theoretical background of restaurant customer satisfaction and return patronage. The research methodology applied in conducting the research and the empirical findings are explained. The article concludes with a discussion of the managerial implications and limitations of the findings and proposes directions for future research.

\section{THEORETICAL BACKGROUND}

Tourism is regarded as one of the fastest growing industries worldwide. The World Travel \& Tourism Council (WTTC, 2010:3) expects an increase in the global travel and tourism industry's contribution towards gross domestic product (GDP) from $9.2 \%$ in 2010 to $9.6 \%$ by 2020 . The WTTC furthermore estimates a rise in total employment by the travel and tourism industry from nearly 236 million jobs in 2010 to more than 303 million by 2020. The South African tourism industry is also regarded as one of the 
fastest growing sectors of the country's economy (RSA NDT, 2011:1). It contributed three per cent of South Africa's GDP and directly employed 527630 persons in 2005 (SSA, 2009:1).

Restaurants are classified as one of the subsectors of the South African tourism industry (THETA, 2004:2). The Tourism Satellite Account for 2005 (SSA, 2009:41,44) estimated that the subsector constituted 1.66 per cent of the tourism industry's contribution towards the gross domestic product (GDP) of South Africa and provided for 68705 jobs in the tourism industry in 2005. It is therefore a small segment of the tourism industry with an economic impact comparable to that of the sport and recreational subsector.

The Tourism Satellite Account, however, only reports on tourists' contribution of 36 per cent towards restaurants' total domestic supply and therefore excludes the 74 per cent contribution by other consumers. Statistics South Africa (SSA, 2007:20) estimates that restaurants employed almost 93000 employees in 2007, while the total income generated by restaurants and coffee shops increased from R1 452 million in September 2009 to R1 592 million in September 2010 (SSA, 2010:3).

The restaurant industry is regarded as one of the largest sectors of the Western economies (Mueller et al., 2003:403). It is the largest private sector employer in the United States of America (USA), employing nearly 13 million people and contributing four per cent to the USA GDP in 2009 (National Restaurant Association, 2010:4). The Australian restaurant industry also performs well. It employed roughly 242200 people and contributed 1.3 per cent to the Australian GDP in 2007 (Restaurant \& Catering Australia, 2009:1).

The growth in the restaurant industry over the past years can be attributed mainly to a change in the modern way of life. Consumers are nowadays experiencing an increasing scarcity of time. As a result, consumers prefer to eat out rather than to spend their scarce time cooking meals at home. This triggered a tendency to consume food away from home (Andaleeb \& Conway, 2006:3). The tendency is most evident in developed countries (Vink, Kirsten \& Woermann, 2004:225) and amongst high-income households (Frazão, Maede \& Regmi, 2008:25). It is estimated that developed countries' consumers spend more than fifty per cent of their total food consumption on food that is consumed away from home (Vink et al., 2004:225), while high-income households spend $47 \%$ of their total food consumption in this way (Frazão et al., 2008:25).

Despite the increasing popularity of eating out (Andaleeb \& Conway, 2006:3) and the continued growth of the restaurant subsector (SSA, 2010:3), the international failure rate for restaurants is considered to be higher than the average failure rate for small businesses. Parsa, Self, Njite and King (2005:305) estimated that thirty per cent of restaurants fail during the first year of operation, although claims are made that it is closer to ninety per cent. Researchers (Soriano, 2002:1065; Chi \& Gursoy, 2009:251) identify restaurateurs' inability to satisfy their customers' expectations and needs as one of the main reasons for restaurant failure.

It has become increasingly difficult to satisfy restaurant customers (Enz, 2004:327; Reynolds \& Biel, 2007:352; Hu, 2009). Restaurant customers progressively demand higher quality food (Hu, 2009) and better service (Quan \& Wang, 2004:297) than before. In addition, restaurant managers also experience pressure from steady increases in food and labour costs, small profit margins, the burden of complying with stringent legal requirements (Enz, 2004:319; Hu, 2009) and fierce competition (Enz, 2004:324; Reynolds \& Bie, 2007:353; Hu, 2009).

The Tourism and Skills Audit conducted by the Tourism, Hospitality and Sport Education and Training Authority (THETA, 2007:36, 41) revealed an estimated shortage of 24100 chefs and 23500 waiters in South Africa. Employers identified applicants and employees' lack of customer care orientation as one of the main reasons why they found it difficult to fill these positions. Frontline employees furthermore do not know why they should deliver great service while they are often not treated with respect (RSA NDT, 2011:55). The industry is furthermore characterised by poor training and development, limited career 
progression, and low salary levels (RSA NDT, 2011:40). In order to address these challenges, and to accelerate the responsible growth of the South African tourism industry from 2010 to 2015, the Minister of Tourism (RSA NDT, 2011:17) identified the development of people and the provision of decent work to tourism employees; and the provision of world-class service to consumers as two of the eleven strategic objectives of the National Tourism Sector Strategy.

International researchers have investigated restaurant customer satisfaction and return patronage from various perspectives. Soriano (2002:1064) found that quality of food, service quality, cost and ambience were linked to return patronage in up-scale Spanish restaurants. In 2004, Iglesias and Guillén (2004:377) determined that perceived quality had a positive effect on customer satisfaction. In the same year, Sulek and Hensley $(2004: 235,243)$ found that food quality, a restaurant's atmosphere and the fairness of the seating procedure had a significant effect on customer satisfaction. Their research identified only food as a significant contributor to customer return patronage. Yüksel and Yüksel (2004:52) also established in 2004 that service quality had the most significant effect on the dining satisfaction amongst 449 departing tourists in Turkey. Andaleeb and Conway (2006:8) assessed the customer satisfaction of 119 respondents in the full service restaurant industry and identified three significant factors that influence customer satisfaction: quality of service, followed by price and food quality. In their study on the consumption behaviour of restaurant customers, Chow et al. (2007:706) found a significant link between service quality and customer satisfaction, as well as between service quality and repeat patronage, but not a significant link between customer satisfaction and repeat patronage. In 2009, Wu and Liang (2009:591) found that the restaurant environment, food and customer service encounters were major factors influencing customer satisfaction. However, none of the researchers investigated customer satisfaction and return patronage from a mall restaurant perspective.

Research about the link between certain demographical variables and restaurant customer satisfaction and return patronage is unclear. In his study on restaurant guests' return patronage in restaurants in Spain, Soriano (2002:1065) found that male and female restaurant guests did not rate the dining attributes quality of food, service, value and ambience differently. Chow et al. (2007:705-706) found no significant relation between Chinese female restaurant guests and return patronage. Kivela, Inbakaran and Reece (2000:196), however, found in Hong Kong that age is significantly related to the return patronage of male restaurants guests, but not to the return patronage of female restaurant guests. Chow et al. (2007:705706) found a significant link between restaurant guests' age and return patronage, and Moschis, Curasi and Bellenger (2003:52) state that mature consumers (older than 55 years) are historically regarded to be more loyal than consumers of other age groups.

The mall manager and marketing manager of a Bloemfontein mall (hereafter referred to as mall management) recognised the importance of customer satisfaction and return patronage for the continued success of the mall and its restaurants. They approached the researcher to gain more insight about customers' satisfaction and return patronage in the mall's restaurants.

\section{RESEARCH QUESTIONS}

The research questions were conceptualised by taking into account the concerns raised by the mall management and restaurateurs, namely:

- Which dining attributes are important for customer satisfaction and return patronage in mall restaurants?

- Is there a difference in restaurant customers' satisfaction and return patronage levels, based on their demographic characteristics?

- Is there a difference in restaurant customers' satisfaction and return patronage in the respective mall restaurants? 


\section{METHODOLOGY}

The mall houses 120 leading retail outlets, six movie theatres, a games arcade and twelve restaurants. Eight of the 12 restaurants were included in the study. These restaurants complied with the criteria set by SSA (2007:31) for classification as a restaurant, namely "Enterprises involved in the sale and provision of meals and drinks, ordered from a menu, prepared on the premises for immediate consumption and with provided seating." The other food and beverage outlets could not be classified as restaurants, but as fastfood outlets and were therefore excluded. These enterprises provide food and beverages intended for takeaway purposes and in a packaged format.

A mixed-methods research design (McMillan \& Schumacher, 2006:27) was followed. An exploratory discussion meeting (qualitative) was held with six of the eight mall restaurateurs, the mall manager and the marketing manager to explore their views on the study. The group interview was followed by the development and completion of structured questionnaires (quantitative) by mall restaurant customers in order to collect data for the study.

The purpose and extent of the study were discussed with the mall managers and restaurateurs during the scheduled meeting. They were also given the opportunity to raise their expectations and concerns about the study. Based on the outcomes of the meeting, the research design needed to be guided by three overriding concerns. Firstly, the restaurateurs and managers of the mall stipulated that the questions had to cover the most important attributes that might have impacted on customer satisfaction and return patronage. Secondly, limited questions on the demographics of the respondents had to be included. Thirdly, the restaurateurs prescribed that the data collection should not have a disruptive effect on the customers' dining experience. They required that the questionnaire should not exceed one page in length, should be self-explanatory and easy to read.

Two standard surveys, namely the SERVQUAL (developed by Parasuraman, Zeithaml \& Berry in 1988) and DINESERV (developed by Stevens et al. in 1995) have been applied in previous restaurant research, but were deemed unsuitable for this study. The SERVQUAL questionnaire was too long and not restaurant-specific (Kivela, Inbakaran \& Reece, 1999a:208; O'Neil \& Palmer, 2001:189; Sulek \& Hensley, 2004:239). Although the DINESERV questionnaire was restaurant specific, it was also too long (Sulek \& Hensley, 2004:239) and one of the essential components of the dining experience, namely the quality of food, was omitted in the measure (Namkung \& Jang 2008:143). Consequently, a self-administered questionnaire was customised to address the objectives and setting of the study.

Questions related to respondents' gender, age, home language, permanent residence, and involvement in a relationship were included in the questionnaire. Restaurant guests were requested to rate their satisfaction with the following dining attributes: food quality, service quality, ambience, the quality of physical facilities, and restaurant management presence. The first three descriptors were selected, since the extensive literature review identified these factors as the most obvious determinants of restaurant customer satisfaction and return patronage (Susskind, 2002:75; Soriano, 2002:1064; Sulek \& Hensley, 2004:236). Discussions with mall management and restaurateurs called for the inclusion of the latter two attributes on the questionnaire. They were of the opinion that ambience dealt more with the sensory and emotional aspects of a facility (e.g. privacy, comfort, lighting, music, temperature) while the quality of the physical facilities addressed the tangible aspects of the facilities. These included aspects such as clean and well-maintained facilities, furniture and equipment, tidy workstations and good quality furniture, equipment, as well as wall and floor coverings. It was believed that management presence could have a significant impact on customer satisfaction, since restaurant managers are generally responsible for ensuring that restaurant customers are satisfied. It is expected of restaurant managers to be involved with their customers and service employees and to check on all customers' meals at least once. 
The independent variables were tested by requesting restaurant guests to rate their overall dining satisfaction and intent to return to the restaurant (return patronage). A five-point Likert scale was used. Since each point in the Likert scale had a descriptor, a fully anchored rating scale (Johnson \& Christensen, 2004: 171) was applied. The five response alternatives for the five dining attributes and overall dining satisfaction were very dissatisfied (1), moderately dissatisfied (2), neither satisfied nor dissatisfied (3), moderately satisfied (4) and very satisfied (5). The response alternatives for customers' intention to return to the restaurant were definitely not (1), probably not (2), unsure (3), probably (4) and definitely (5).

The clarity of the instructions, ease of completing the questionnaire and time taken to complete the questionnaire (Leedy \& Ormrod, 2005:188) were piloted using ten guests dining at a full service restaurant and the questionnaire was also distributed to the mall management and restaurateurs of the mall for their input. No changes were made to the questionnaire.

The study was voluntary and verbal consent was obtained from all the restaurateurs. Restaurateurs were assured that all information collected would be treated as anonymous. The results of the study would be made known to all restaurateurs. It was, however, agreed that the identity of all restaurants would only be revealed to the management of the mall, while each restaurateur would only be informed of the identity of his or her own restaurant.

The population of the study was regarded as all the restaurant customers of the mall. A proportional stratified sampling design (Leedy \& Ormrod, 2005:203) was followed to calculate the sample size. The sample size per restaurant in this study was calculated at 50 per cent of each restaurant's seating capacity. This sampling method is comparable to the technique used by Kivela, Reece and Inbakaran (1999b:274). These researchers calculated the sample size per restaurant at 25 per cent of each restaurant's seating capacity for lunch and dinner.

Restaurants were visited for data collection from Wednesdays to Sundays, after 12:00, over a six-week period. These days, as well as the specific time of the day, were considered to be the busiest times and days of the week and they best suited the programmes of restaurateurs. Questionnaires were provided by the waiter and a hospitality management graduate to the restaurant customer who was presented with the bill. The graduate explained the purpose of the survey, indicated that participation was voluntary and requested one guest per table to complete the questionnaire voluntarily. Random sampling (Leedy \& Ormrod, 2005:199) was therefore used. Completed questionnaires were collected by hospitality management graduates upon payment of the bill.

\section{FINDINGS}

\section{Reliability and validity}

Reliability in quantitative studies can be defined as the extent to which test scores are accurate, consistent or stable (Struwig \& Stead, 2001:130). Taking into account that McMillan and Schumacher (2006:186) regard the Cronbach a coefficient as the most appropriate method to investigate the reliability of survey research where there is a range of possible answers and not only a choice between two items, internal reliability was tested using this measure. A Cronbach's a coefficient of higher than seven is acceptable (Pietersen \& Maree, 2007:216). The Cronbach`s a coefficient for the total index was high (0.8766), while moderate to high reliability coefficients were calculated for food quality $(0.8619)$, service quality $(0.8518)$, ambience $(0.8522)$ quality of facilities $(0.8572)$, management presence $(0.8652)$, overall dining satisfaction (0.8399) and return patronage $(0.8807)$. The high alpha values indicate good internal consistency among the items. 
Pietersen and Maree (2007:216) describe validity as the extent to which an empirical instrument "measures what it is supposed to measure". In order to ensure content and face validity (Babbie \& Mouton, 2008:122), a literature study was undertaken and the survey instrument was scrutinised by academic and restaurant experts before the instrument was finalised.

\section{Results and discussion}

A total of 590 fully completed questionnaires were gathered, which corresponded with the calculated sample size per restaurant. The respondents' demographic profile is depicted in Table 1. Of the 590 respondents, $43 \%(n=253)$ were male. The median age of the respondents was 34 years (inter-quartile range: 23-44 years). Most of the respondents were in the age group 18 to 24 years (31\%), followed by respondents in the age group 35 to 44 years. Afrikaans was the language most frequently used by respondents (75\%), followed by English (15\%). Most of the respondents $(53 \%)$ were involved in permanent relationships and permanently resided in Bloemfontein (71\%).

Table 1: Demographic information and overall means and standard deviations

\begin{tabular}{|c|c|c|c|c|c|c|c|c|c|c|c|c|c|c|c|c|}
\hline \multirow{3}{*}{$\begin{array}{l}\text { Demographic } \\
\text { variables }\end{array}$} & \multirow{3}{*}{$\mathbf{n}$} & \multirow{3}{*}{$\%$} & \multicolumn{10}{|c|}{ Dining attributes } & \multirow{2}{*}{\multicolumn{2}{|c|}{ Overall }} & \multirow{2}{*}{\multicolumn{2}{|c|}{$\begin{array}{c}\text { Return } \\
\text { patronage }\end{array}$}} \\
\hline & & & \multicolumn{2}{|c|}{$\begin{array}{c}\text { Food } \\
\text { quality }\end{array}$} & \multicolumn{2}{|c|}{$\begin{array}{l}\text { Service } \\
\text { quality }\end{array}$} & \multicolumn{2}{|c|}{ Ambience } & \multicolumn{2}{|c|}{$\begin{array}{c}\text { Facilities } \\
\text { quality }\end{array}$} & \multicolumn{2}{|c|}{$\begin{array}{c}\text { Manage- } \\
\text { ment }\end{array}$} & & & & \\
\hline & & & $M$ & SD & $M$ & SD & M & SD & $M$ & SD & $\mathbf{M}$ & SD & M & SD & M & SD \\
\hline Gender & & & & & & & & & & & & & & & & \\
\hline $\begin{array}{l}\text { Male } \\
\text { Female }\end{array}$ & $\begin{array}{l}253 \\
335\end{array}$ & $\begin{array}{l}43 \\
57\end{array}$ & $\begin{array}{l}4.32 \\
4.27\end{array}$ & $\begin{array}{l}0.75 \\
0.81\end{array}$ & $\begin{array}{l}4.14 \\
4.16\end{array}$ & $\begin{array}{l}0.99 \\
0.93\end{array}$ & $\begin{array}{l}3.98 \\
4.12\end{array}$ & $\begin{array}{l}0.95 \\
0.91\end{array}$ & $\begin{array}{l}3.96 \\
3.98\end{array}$ & $\begin{array}{l}0.94 \\
0.99\end{array}$ & $\begin{array}{l}3.69 \\
3.79\end{array}$ & $\begin{array}{l}1.25 \\
1.17\end{array}$ & $\begin{array}{l}4.19 \\
4.22\end{array}$ & $\begin{array}{l}0.80 \\
0.90\end{array}$ & $\begin{array}{l}4.59 \\
4.56\end{array}$ & $\begin{array}{l}0.60 \\
0.73\end{array}$ \\
\hline Age & & & & & & & & & & & & & & & & \\
\hline $18-24$ ye & 181 & 31 & 4.29 & 0.76 & 4.10 & 0.96 & 4.04 & 0.94 & 3.99 & 0.94 & 3.76 & 1.26 & 4.25 & 0.85 & 4.56 & 0.67 \\
\hline 25 & 127 & 21 & 4.27 & 0.83 & 4.02 & 1.08 & 3.9 & & 3.80 & 1.08 & 3.67 & 1.21 & 4.06 & 0.97 & & 80 \\
\hline $35-4$ & 135 & 23 & 4.36 & 0.78 & 4.29 & 0.85 & 4.12 & 0.90 & 4.03 & 0.95 & 3.79 & 1.21 & 4.2 & 0.78 & & \\
\hline $45-54$ yea & 92 & 16 & 4.24 & 0.87 & 4.34 & 0.88 & 4.17 & 0.93 & 4.12 & 0.92 & 3.85 & 1.17 & 4.22 & 0.87 & 4.62 & 0.61 \\
\hline 55 years & 55 & 9 & 4.29 & 0.63 & 4.02 & 0.95 & 3.96 & 0.86 & 3.84 & 0.88 & 3.62 & 1.10 & 4.18 & 0.77 & 4.65 & 0.55 \\
\hline Relationship status & & & & & & & & & & & & & & & & \\
\hline Perm & 315 & 53 & 4.28 & 0.79 & 4.15 & 0.96 & 4.06 & 0.94 & 3.99 & 0.92 & 3.76 & 1.18 & 4.21 & 0.83 & 4.58 & 0.68 \\
\hline Not in perr & 275 & 47 & 4.30 & 0.78 & 4.16 & 0.95 & 4.04 & 0.93 & 3.94 & 1.03 & 3.74 & 1.23 & 4.20 & 0.89 & 4.56 & 0.67 \\
\hline Language & & & & & & & & & & & & & & & & \\
\hline & 444 & 75 & 4.31 & 0.76 & 4.17 & 0.95 & 4.09 & 0.90 & 3.96 & 0.96 & 3.73 & 1.21 & 4.22 & 0.84 & 4.60 & 0.66 \\
\hline Engl & 90 & 15 & 4.17 & 0.80 & 4.07 & 0.88 & 3.5 & $0 . \subseteq$ & 3.93 & 0.93 & 3.68 & 1.19 & 4.11 & 0.81 & & 30 \\
\hline Other & 56 & 10 & 4.38 & 0.93 & 4.16 & 1.16 & 3.93 & 1.17 & 4.09 & 1.10 & 3.96 & 1.22 & 4.27 & 1.07 & 4.71 & 0.49 \\
\hline Permar & & & & & & & & & & & & & & & & \\
\hline Bloe & 416 & 71 & 4.32 & 0.76 & 4.12 & 0.97 & 4.06 & 0.95 & 3.96 & 0.96 & 3.72 & 1.21 & 4.20 & 0.85 & 4.58 & 0.69 \\
\hline Other & 174 & 29 & 4.22 & 0.85 & 4.25 & 0.92 & 4.03 & 0.88 & 3.97 & 1.00 & 3.81 & 1.19 & 4.22 & 0.88 & 4.56 & 0.69 \\
\hline All & 590 & 100 & 4.29 & 0.79 & 4.16 & 0.96 & 4.05 & 0.93 & 3.97 & 0.97 & 3.75 & 1.21 & 4.20 & 0.86 & 4.58 & 0.68 \\
\hline
\end{tabular}

Table 1 depicts the variable mean scores and standard deviations calculated for the total sample and different demographic groups. An initial glance at the data reveals that respondents' satisfaction levels varied from 3.75 for management presence to 4.29 for food quality, with five being the highest possible score. Respondents were moderately to very satisfied with the overall dining experience (4.20) and reported a high return patronage (4.58). Standard deviations between 0.68 (return patronage) and 1.21 (management presence) were calculated.

Pearson's product-moment correlation coefficient and regression analysis were used to investigate the relationship of overall dining satisfaction (dependent variable) with the five dining attributes (independent variables) and the relationship of the return patronage (dependent variable) with the five dining attributes and overall dining satisfaction (independent variables). The results of the correlation analysis are depicted in Table 2. 
Table 2: Correlation results of overall dining satisfaction and return patronage

\begin{tabular}{|l|c|c|c|c|}
\hline \multirow{2}{*}{ Variables } & \multicolumn{2}{|c|}{ Overall dining satisfaction } & \multicolumn{2}{c|}{ Return patronage } \\
\cline { 2 - 5 } & $\begin{array}{c}\text { Correlation } \\
\text { coefficient (r) }\end{array}$ & $\begin{array}{c}\text { Significance } \\
\text { (p-value) }\end{array}$ & $\begin{array}{c}\text { Correlation } \\
\text { coefficient (r) }\end{array}$ & $\begin{array}{c}\text { Significance } \\
\text { (p-value) }\end{array}$ \\
\hline Food quality & 0.65 & $<.0001^{*}$ & 0.39 & $<.0001$ \\
\hline Service quality & 0.64 & $<.0001^{*}$ & 0.40 & $<.0001$ \\
\hline Ambience & 0.63 & $<.0001^{*}$ & 0.38 & $<.0001$ \\
\hline Facilities quality & 0.58 & $<.0001^{*}$ & 0.32 & $<.0001$ \\
\hline Management presence & 0.59 & $<.0001^{*}$ & 0.32 & $<.0001$ \\
\hline Overall dining satisfaction & - & - & 0.50 & $<.0001$ \\
\hline
\end{tabular}

The data revealed that all five of the dining attribute variables showed a moderate to strong positive correlation $(r>0.5)$ with overall dining satisfaction. All five dining attributes had a significant correlation $(p<0.05)$ with customers' overall dining satisfaction. The strongest correlation with overall dining satisfaction was food quality $(r=0.65)$.

A similar examination of the relationship between the six independent variables and customers' return patronage showed that all the variables had a weak to moderate $(r \leq 0.5)$ positive correlation with customer return patronage. The weakest correlations with customer return patronage were calculated for the quality of facilities and management presence $(r=0.32)$. All six independent variables had a significant positive correlation $(p<0.05)$ with customers' return patronage. Overall dining satisfaction had the strongest correlation with customers' return patronage $(r=0.50)$, followed by food quality $(r=0.40)$.

Full regression models were run for each of the two dependent variables. The first full model regressed the five dining attributes against overall dining satisfaction, while the second full model regressed the five dining attributes and overall dining satisfaction against customer return patronage. Both full regression models are depicted in Table 3.

Table 3: Regression results of overall dining satisfaction and return patronage

\begin{tabular}{|l|c|c|c|c|}
\hline \multirow{2}{*}{ Independent variables } & \multicolumn{2}{|c|}{$\begin{array}{c}\text { Model 1: } \\
\text { Model 2: } \\
\end{array}$} & Overall dining satisfaction & \multicolumn{2}{c|}{\begin{tabular}{c} 
Return patronage \\
\cline { 2 - 5 }
\end{tabular}} & t-value & p-value (p) & t-value & p-value (p) \\
\hline Food quality & 10.45 & $<.0001^{*}$ & 2.09 & $0.0367^{*}$ \\
\hline Service quality & 5.45 & $<.0001^{*}$ & 1.89 & 0.0593 \\
\hline Ambience & 4.78 & $<.0001^{*}$ & 1.22 & 0.2231 \\
\hline Facilities quality & 2.49 & $<.0131^{*}$ & -0.32 & 0.7492 \\
\hline Management presence & 7.81 & $<.0001^{*}$ & 0.41 & 0.6818 \\
\hline Overall dining satisfaction & & & 5.50 & $<.0001^{*}$ \\
\hline
\end{tabular}

${ }^{*}$ indicates significant relation $(p<0.05)$

The first full regression model showed that all five dining attribute variables were significantly related $(p<0.05)$ to customers' overall dining experience. The t-values in Table 3 indicate the relative importance of each attribute in predicting overall dining satisfaction. The quality of food ( $t=10.45)$ was rated by respondents as the most important variable for overall dining satisfaction, followed by the presence of management $(\mathrm{t}=7.81)$, service quality $(\mathrm{t}=5.45)$, ambience $(\mathrm{t}=4.78)$ and facilities quality $(\mathrm{t}=2.49)$.

A study performed by Sulek and Hensley (2004:242) also found that food quality ranked highest amongst the factors that had an impact on restaurant customer satisfaction, but Andaleeb and Conway (2006:8) found that food quality ranked third highest. Previous research showed that service quality (Yüksel \& Yüksel, 2004:52; Andaleeb \& Conway, 2006:8; Chow et al., 2007:706; Wu \& Liang, 2009:591) and restaurant ambience (Sulek \& Hensley, 2004:242; Wu \& Liang, 2009:591) had a significant impact on 
restaurant customers' satisfaction. The idea, brought up for discussion by the restaurateurs and mall management, that the quality of physical facilities and management presence could play an important role in overall customer satisfaction was confirmed by the findings of this study.

The model F-value was calculated at $33.64(p<0001)$. The five dining attributes had a coefficient determination $\left(R^{2}\right)$ of 0.6344 and thus explained more than 63 per cent of the variability in overall dining satisfaction. This explanation of the variability in overall dining satisfaction is high when compared to other studies. For example, the regression results of a study performed by Sulek and Hensley (2004), identified food, dining atmosphere and seating order as significant predictors $(p<0.05)$ of restaurant customer satisfaction, which explained only 51 per cent of restaurant customers' satisfaction.

The second full regression model depicted in Table 3 showed that only food quality $(p=0.0367)$ and overall dining satisfaction $(p<0.0001)$ were significantly related $(p<0.05)$ to customers' return patronage. The tvalues of the second model indicated that respondents rated overall dining satisfaction $(\mathrm{t}=5.50)$ as the most important variable in their decision to return to a restaurant, followed by food quality ( $\mathrm{t}=2.09$ ). Previous research studies confirmed the important role of overall satisfaction (Ganesh et al., 2000: 66; Soriano, 2002:1057; Susskind, 2002:84; Barsky \& Nash, 2003:173; Iglesias \& Guillén 2004:373; Cheng, 2005:99; Söderlund \& Öhman, 2005:169; Gupta et al., 2007:293; Han et al., 2009:563) and food (Soriano, 2002:1065; Sulek \& Hensley, 2004:243) in restaurant customers' return patronage. Although it might seem surprising that service quality was found not to be a significant contributor to customers' return intention, similar studies by Sulek and Hensley (2004:242) in the USA and Kivela et al. (2000:28) in Hong Kong confirmed that service quality is not a significant contributor to customers' return intention. Physical design and restaurant ambience also did not play a significant role in customers' return patronage in a study by Andaleeb and Conway (2006:8).

The model F-value was calculated at $34.49(p<.0001)$. The five dining attributes and overall dining satisfaction had an $R^{2}$ of 0.2235 per cent and thus explained just more than 22 per cent of the variability in restaurant guests' return patronage. The regression results of a study performed by Sulek and Hensley (2004) identified only food quality as a significant predictor $(p<0.05)$ of restaurant customer patronage, which explained only 17 per cent of customers' return patronage.

The possibility of co-linearity among the dining attributes should not be ignored. Susskind (2002:76), however, states that restaurant customers usually evaluate the components of a service (e.g. food quality, service quality and ambience) in isolation. He states that this type of attribute evaluation is demonstrated by the following classic phrase: "the food was good, but the service was terrible".

A further investigation of Table 1 shows that all the different demographic groups rated their satisfaction with the five restaurant attributes (food quality, service quality, ambience, facilities quality, and management presence) in the range neither satisfied nor dissatisfied (3.62) to very satisfied (4.38) and reported a moderate to very satisfied overall satisfaction level (4.06 to 4.27). Respondents who used another language than English or Afrikaans most frequently reported the highest satisfaction level (4.38) for food and also reported the highest return patronage (4.71). Respondents older than 50 years were the least satisfied with the presence of management (3.62), closely followed by respondents in the age group 25 to 34 (3.67). Three demographic groups (females, age group 18 to 24, and those who do not permanently reside in Bloemfontein) reported the same return patronage level (4.56).

In order to determine whether the levels of customer satisfaction and return patronage of customers from different demographic groups differed in mall restaurants, variable mean scores, standard deviations, ttests and one-way analysis of variance (ANOVA) were calculated for the different demographic groups of respondents. Table 4 reflects the t-tests and one-way ANOVA performed to determine whether there were any significant differences $(p<0.05)$ in the customer satisfaction and return patronage levels reported by the different demographic groups. 
Table 4: The significance of the difference in the means of different demographic groups

\begin{tabular}{|l|c|c|c|c|c|c|c|}
\hline \multirow{2}{*}{ Variables } & \multicolumn{7}{|c|}{ p-values } \\
\cline { 2 - 8 } & Food & Service & Ambience & Facilities & $\begin{array}{c}\text { Manage- } \\
\text { ment }\end{array}$ & Overall & Return \\
\hline Gender & 0.4969 & 0.7838 & 0.0703 & 0.8079 & 0.3040 & 0.6538 & 0.5286 \\
\hline Age & 0.8405 & $0.0399^{*}$ & 0.3804 & 0.1062 & 0.7433 & 0.2877 & 0.6804 \\
\hline Relationship status & 0.7666 & 0.8867 & 0.7967 & 0.5701 & 0.8615 & 0.9695 & 0.6665 \\
\hline Language & 0.2168 & 0.6881 & 0.2621 & 0.5939 & 0.3389 & 0.4846 & $0.0020^{*}$ \\
\hline Permanent residence & 0.1440 & 0.1415 & 0.6679 & 0.9334 & 0.4128 & 0.8079 & 0.7212 \\
\hline
\end{tabular}

* indicates a significant difference $(p<0.5)$

It is clear from Table 4 that there was no significant difference in the means $(p<0.05)$ calculated for respondents from different genders, with different relationship statuses and whose place of permanent residence differed. However, respondents from different age groups rated their satisfaction with service quality significantly different $(p<0.05)$, while respondents who made use of different languages rated only their return patronage significantly different $(p<0.05)$.

A comparison of customers' satisfaction and return patronage levels in the eight mall restaurants is provided in Table 5. This table depicts the variable mean scores and standard deviations calculated for the five dining attributes, overall dining satisfaction and return patronage in the respective restaurants and also for all the restaurants.

Table 5: Means and standard deviations for the five dining attributes, overall dining satisfaction and return patronage in the respective mall restaurants

\begin{tabular}{|c|c|c|c|c|c|c|c|c|c|c|c|c|c|c|c|}
\hline \multirow{3}{*}{$\begin{array}{l}\text { Restau- } \\
\text { rant }\end{array}$} & \multirow{3}{*}{$\mathbf{n}$} & \multicolumn{10}{|c|}{ Dining attributes } & \multirow{2}{*}{\multicolumn{2}{|c|}{$\begin{array}{c}\text { Overall } \\
\text { satisfaction }\end{array}$}} & \multirow{2}{*}{\multicolumn{2}{|c|}{$\begin{array}{c}\text { Return } \\
\text { patronage }\end{array}$}} \\
\hline & & \multicolumn{2}{|c|}{$\begin{array}{c}\text { Food } \\
\text { quality }\end{array}$} & \multicolumn{2}{|c|}{$\begin{array}{l}\text { Service } \\
\text { quality }\end{array}$} & \multicolumn{2}{|c|}{ Ambience } & \multicolumn{2}{|c|}{$\begin{array}{c}\text { Facilities } \\
\text { quality }\end{array}$} & \multicolumn{2}{|c|}{$\begin{array}{c}\text { Manage- } \\
\text { ment }\end{array}$} & & & & \\
\hline & & $M$ & SD & $M$ & SD & $\mathbf{M}$ & SD & $M$ & SD & M & SD & $\mathbf{M}$ & SD & $\mathbf{M}$ & SD \\
\hline$A$ & 66 & 4.30 & 0.88 & 4.55 & 0.61 & 4.26 & 0.85 & 4.15 & 0.90 & 4.09 & 0.99 & 4.44 & 0.70 & 4.59 & 0.58 \\
\hline$B$ & 58 & 4.43 & 0.62 & 4.28 & 0.72 & 4.12 & 0.84 & 3.74 & 1.00 & 3.60 & 1.18 & 4.19 & 0.78 & 4.77 & 0.57 \\
\hline$C$ & 123 & 4.36 & 0.83 & 4.09 & 1.02 & 4.11 & 0.97 & 4.04 & 0.99 & 3.59 & 1.29 & 4.22 & 0.91 & 4.67 & 0.75 \\
\hline $\mathrm{D}$ & 68 & 4.15 & 0.81 & 3.82 & 1.01 & 3.74 & 1.14 & 3.66 & 1.06 & 3.34 & 1.40 & 3.94 & 1.02 & 4.40 & 0.81 \\
\hline$E$ & 75 & 4.35 & 0.73 & 4.05 & 1.21 & 4.04 & 0.94 & 3.93 & 1.00 & 3.97 & 1.11 & 4.22 & .81 & 4.45 & 0.86 \\
\hline$F$ & 108 & 4.19 & 0.83 & 4.24 & 0.93 & 4.05 & 0.93 & 4.06 & 0.94 & 3.97 & 1.11 & 4.22 & 0.86 & 4.60 & 0.51 \\
\hline $\mathrm{G}$ & 52 & 4.23 & 0.73 & 4.11 & 0.88 & 4.06 & 0.73 & 4.02 & 0.78 & 3.73 & 1.07 & 4.15 & 0.75 & 4.56 & 0.60 \\
\hline $\mathrm{H}$ & 40 & 4.38 & 0.67 & 4.15 & 0.89 & 4.05 & 0.85 & 4.00 & 0.96 & 3.55 & 1.22 & 4.23 & 0.89 & 4.58 & 0.50 \\
\hline All & 590 & 4.29 & 0.79 & 4.15 & 0.96 & 4.05 & 0.93 & 3.97 & 0.97 & 3.75 & 1.21 & 4.21 & 0.86 & 4.57 & 0.68 \\
\hline
\end{tabular}

Restaurant A obtained the highest levels of customer satisfaction for its quality of service (4.55), ambience (4.26), quality of facilities (4.15), management presence (4.09) and overall dining satisfaction (4.44). Restaurant B obtained the highest customer satisfaction ratings for food quality (4.43) and return patronage (4.77). Although Restaurant D scored the lowest customer satisfaction ratings for four of the five independent variables tested, above average ratings of between 3.34 to 4.15 were obtained. This restaurant also obtained the lowest mean scores for the two dependent variables overall satisfaction (3.94) and return patronage (4.40).

An ANOVA was performed to determine whether there were any significant differences amongst the means of the eight mall restaurants calculated for the five dining attributes, overall dining satisfaction, and return patronage in the eight mall restaurants (see Table 6). 
Table 6: ANOVA results for the five dining attributes, overall dining satisfaction and return patronage in the respective mall restaurants

\begin{tabular}{|l|c|c|c|c|c|}
\hline Source of variation & Df & $\begin{array}{c}\text { Sum of } \\
\text { squares }\end{array}$ & $\begin{array}{c}\text { Mean } \\
\text { square }\end{array}$ & F-value & $\begin{array}{c}\text { Significance } \\
\text { (p-value) }\end{array}$ \\
\hline Food quality & 7 & 5.02 & 0.72 & 1.16 & 0.3227 \\
\hline Service quality & 7 & 20.56 & 2.94 & 3.30 & $0.0019^{*}$ \\
\hline Ambience & 7 & 10.25 & 1.46 & 1.70 & 0.1068 \\
\hline Facilities quality & 7 & 13.51 & 1.93 & 2.08 & $0.0438^{*}$ \\
\hline Management presence & 7 & 34.15 & 4.89 & 3.46 & $0.0012^{*}$ \\
\hline Overall dining satisfaction & 7 & 8.62 & 1.23 & 1.68 & 0.1102 \\
\hline Return patronage & 7 & 4.95 & 0.71 & 1.55 & 0.1471 \\
\hline
\end{tabular}

* indicates a significant difference $(p<0.5)$

Significant differences $(p<0.05)$ among the means were only obtained for service quality $(p=0.0019)$, facilities quality $(p=0.0438)$ and management presence $(p=0.0012)$, which indicates that respondents experienced significant differences in mall restaurants' service quality, facilities quality and management presence.

\section{CONCLUSION AND MANAGERIAL IMPLICATIONS}

The managerial implications pertaining to restaurant customers' satisfaction, their return patronage, demographic characteristics, and the levels of customer satisfaction and return patronage in the different mall restaurants are discussed in the following sections.

\section{Restaurant customers' satisfaction}

Restaurateurs should continuously strive to increase the levels of customer satisfaction by emphasising the five significant dining attributes for overall customer satisfaction, namely food quality, service quality, ambience, the quality of facilities, and management presence. Food quality had the strongest influence on customers' overall dining experience, and management should therefore focus most of their attention and money on this dining attribute.

Food and service quality standards need to be developed and articulated to employees in a way that is generally accepted, clear and understood by all employees. Similar standards should be developed for the quality of facilities, ambience and management presence. These standards will act as a guide for employees and can motivate employees and supervisors to support one another (Susskind, Kacmar \& Borchgrevink, 2007:372).

Restaurateurs should develop appropriate training and empowerment programmes for all employees. Empowered employees tend to be satisfied employees who feel more motivated and positive about their jobs. This increase in job satisfaction has the potential to generate higher levels of customer satisfaction and employee retention (Dutta, Venkatesh \& Parsa, 2007:360; Susskind et al., 2007:370). Even though restaurateurs should develop the overall human capital of their restaurants, they should place specific emphasis on the development of their frontline employees. Frontline employees transfer most of the value of the restaurant product to the customers when they interact with the customers. Frontline employees are therefore responsible for the "moment of truth" or "critical fail point" when customers evaluate the restaurant as a whole. Attention needs to be paid to the development of frontline characteristics such as emotional intelligence and creativity (Namasivayam \& Denizci, 2006:385, 391).

Restaurateurs need to realise that a superior working environment creates satisfied employees, which in turn improves customer satisfaction (Chi \& Gursoy, 2009:252). South African frontline staff seems to be ignorant about the reasons why they ought to deliver great service and are often not treated with respect 
(RSA NDT, 2011:55). In order to improve customer satisfaction levels, restaurateurs should provide decent work to all their employees. Restaurateurs need to treat employees fairly, pay decent wages and provide them with career progression opportunities.

Restaurateurs should conduct customer satisfaction surveys at regular intervals to monitor the attributes that have an impact on customer satisfaction in order to obtain pertinent managerial information. These surveys can also act as confirmation to customers that restaurateurs value their input and actively strive to improve the customer experience. Periodically repeating the process can also enable restaurateurs to spot trends in customers' perceptions. In addition, it can also alert the manager to changes in the relative importance of the variables, which might impact on overall dining satisfaction. Regular satisfaction and return patronage surveys could act as an early warning system, since a decline in customer satisfaction does not usually affect the financial viability of a restaurant immediately. It can enable restaurateurs to take immediate action so as to reverse the decline before it affects the restaurants' financial performance. The data collected from regular customer satisfaction surveys will not only be useful to improve restaurant customer satisfaction, but can also be used as a base for bonus and incentive schemes for employees such as best manager, employee of the year, etc. This might lead to employee satisfaction which might in turn have a positive impact on customer satisfaction. Restaurateurs should also understand that attempts to increase customer satisfaction may have a positive impact on restaurant employees' job satisfaction levels. If restaurant customers complain less, employees might feel more satisfied and positive about their jobs (Bernhardt et al., 2000:169).

\section{Restaurant customers' return patronage}

Restaurateurs should focus on the attributes significantly related to customers' return patronage, namely overall dining satisfaction and food quality. They need to consider whether the expense and time that would be incurred to improve food quality or overall dining satisfaction will render a sufficient return on investment from repeat sales to loyal customers. Some of the attributes that impact on restaurant customer satisfaction did not have an effect on customers' return patronage. It is not surprising, since one does not usually expect a restaurant customer to return to a restaurant just because of the quality of the facilities or the presence of management. The likely reason as to why quality of service, quality of facilities and the presence of management matter so little to customers' return intentions might be attributed to the fact that customers will only notice these attributes when severe problems occur.

Restaurateurs should consider other variables that might have an impact on customers' return patronage, since customer's satisfaction with the five dining attributes and overall dining satisfaction provided a limited explanation of the variability in restaurant guests' return patronage.

Restaurateurs should take note of the role that emotion plays in customers' satisfaction and return patronage. Han et al. (2009:563) suggest that restaurant customers' satisfaction levels are often influenced by their emotional rather than their physical needs. Dining at a restaurant evokes a feeling of comfort, which often impacts on customers' decision to return to a restaurant (Kivela et al., 2000:27). In line with the findings of Kivela et al. (2000:27) and Liu and Jang (2009:502) suggest that restaurant customers' positive and negative emotions have an impact on their post-dining behaviour, while Ladhari et al. (2008:570) found that emotions had a mediating effect on customers' satisfaction levels. Positive emotions (e.g. happiness, pleasure, excitement, contentment and joy) had a greater effect on restaurant customers' satisfaction levels than negative emotions (e.g. anger, frustration, boredom, disgust, embarrassment or sadness). Restaurateurs should therefore aim to reduce negative emotions and should ensure that they convey positive emotions to their customers.

Restaurateurs could encourage the building up of switching barriers to promote return patronage. Han et al. (2009:570) identified the following five switching barriers that influenced dissatisfied customers to return to the same restaurant: preference (e.g. customers personally prefer some of the restaurant attributes, or their friends or family might prefer to dine at the restaurant), monetary switching costs (e.g. customers have a voucher to eat at the restaurant), non-monetary switching costs (e.g. the restaurant is 
conveniently located), relational investment (e.g. the customer might feel that the restaurant offers the best deal), and a lack of alternatives (e.g. the customer is of the opinion that there is not a superior or comparable restaurant nearby). Restaurateurs should, however, be cautious not to rely too much on switching barriers, since dissatisfaction could ultimately lead to disloyalty and negative word-of-mouth (Han et al., 2009:563).

Restaurateurs could also make use of relationship marketing to retain existing customers (Han et al., 2009:563). Kivela et al. (2000:29), however, state that it is difficult to form long-term relationships with every customer, or even with a limited number of repeat customers. Restaurateurs should therefore not only focus on loyalty-inducing behaviour, but also on the attributes important for restaurant customers' return patronage.

\section{Restaurant customers' satisfaction and return patronage based on demographic characteristics}

It is clear from the findings of this study that the demographic variables of restaurant customers had little impact on their customer satisfaction and return patronage levels. Restaurateurs, however, need to recognise the important role that age plays in perceptions regarding restaurant service quality. They should understand that the needs and service quality expectations of respondents from different age groups vary. Market research should be conducted to determine the needs and expectations of restaurant customers from different age groups and appropriate strategies should be developed to meet and exceed the expectations of restaurant customers from different age groups.

Restaurateurs need to develop appropriate strategies to improve on the significantly higher return patronage levels exhibited by respondents who were involved in permanent relationships. Possible reasons for the difference in the return patronage levels of respondents in permanent relationships (e.g. the impact of their partners to return to a specific restaurant) and non-permanent relationships (e.g. respondents are more adventurous) need to be explored.

\section{Restaurant customer satisfaction and return patronage in the respective mall restaurants}

Mall restaurateurs should not underestimate its competition, but should continuously monitor and compare their customer satisfaction and return patronage levels with those of similar restaurants in the mall for the long-term sustainability of the business. Due to restaurant density in the mall, each mall restaurant should aim to differentiate itself from other restaurants. Restaurateurs should therefore focus on service quality, facilities quality and management presence to gain and sustain a competitive advantage over other mall restaurants. Although these dining attributes significantly contribute towards restaurant customers' overall dining satisfaction, respondents' satisfaction for these dining attributes significantly differed in the different mall restaurants.

Mall restaurants obtaining significantly lower customer satisfaction ratings regarding service quality, facilities quality and management presence, should address shortcomings in these areas as a matter of urgency, since it could seriously impact on the long-term sustainability of the restaurants.

In order to improve the recreational and entertainment opportunities offered by the mall, mall management should perform regular customer satisfaction audits on restaurants that obtained significant lower customer satisfaction ratings in service quality, facilities quality and management presence.

The results of this study could be used by the mall management to reward the restaurant with the highest level of overall customer satisfaction in the mall with a special prize and trophy. The comparative analysis will also enable mall management to categorise mall restaurants according to the levels of customer satisfaction experienced by mall restaurant customers. Plaques could be set up at the mall restaurants' entrances to inform restaurant customers about the food quality, service quality, ambience, facilities' quality, management presence and overall dining satisfaction that could be expected in the respective mall restaurants. 


\section{CONCLUSION}

It is usually difficult to obtain the support of restaurateurs for studies of this nature, but in this study, cooperation from the mall's restaurateurs was readily obtained. Restaurant tenants' lease agreements provided for tight quality assurance mechanisms (such as the execution of customer satisfaction surveys) and mall management and restaurateurs acknowledged the value of the research to them. The relationship that existed between the participating restaurants and the mall management enabled the researcher to formulate the research construct and to interpret the quantitative findings more effectively.

This article offers the South African restaurant subsector increased insight into restaurant customers' satisfaction and return patronage. It provides a clear understanding of the attributes responsible for restaurant customers' satisfaction (food quality, service quality, ambience, facilities quality and management presence) and return patronage (overall dining satisfaction and food quality).

The results suggest that the demographic characteristics of restaurant customers had little impact on their customer satisfaction and return patronage levels.

The comparative evaluation of customers' satisfaction and return patronage in the mall's restaurants enables restaurateurs to identify areas of improvement. It also informs mall restaurateurs to focus on service quality, facilities quality and management presence in order to gain and sustain a competitive advantage over other mall restaurants. The comparative evaluation further identified the restaurants and specific dining attributes on which mall management should focus in order to improve the customer satisfaction levels of mall restaurant visitors.

The research supports the strategic objectives of the National Tourism Sector Strategy (RSA NDT, 2011:12) to develop people and to provide decent work for employees in the tourism industry, and to deliver a world-class experience to consumers.

\section{LIMITATIONS}

Despite the importance of this study, it is not free of limitations. Firstly, only the most important attributes that could impact on restaurant customers' satisfaction and return patronage levels were investigated. Limited emphasis was also placed on the dimensions which could be reflective of the identified attributes. Secondly, the first regression model failed to explain 37 per cent of the variation in customer satisfaction, and the second regression model could only explain 78 per cent of the variation in return patronage. Thirdly, the research was based on customer satisfaction experienced in restaurants situated in a specific South African mall. Caution is therefore required when generalising the findings of this study to other segments of the restaurant industry or mall restaurants in other geographic areas, since a replication of this study in other types of restaurants or other geographic areas might reveal varying levels of importance. Lastly, the reliability of the study might have been negatively influenced by the decision to measure restaurant customers' intention to return to a restaurant directly after their dining experience. O'Neil and Palmer (2001:187) warn that customers' decision to return to a restaurant might be different after the dining experience when compared to the time when a decision to return to a restaurant is made. 


\section{FUTURE RESEARCH}

Five areas for future research can be identified. Firstly, the coefficient of determinations of the regression models suggests that additional variables (e.g. positive and negative emotions, employee satisfaction, reasons for visiting the mall and restaurants, safety, parking, and location of the mall) could be considered to explain overall customer satisfaction and return patronage in mall restaurants. Secondly, future studies could compare the important dining attributes for customer satisfaction and return patronage in South African restaurants and take-aways. Thirdly, further research is required to explore the impact of loyalty schemes and switching barriers on restaurant customers' return patronage. Fourthly, the research could be expanded to malls situated in other cities, although it is not expected that the findings would be significantly different. Lastly, triangulation requirements could be considered by applying multiple methods (e.g. surveys, individual interviews and focus group discussions) and multiple data and data sources (e.g. data obtained from mystery customers, waiters and restaurant management) in order to enhance the reliability and validity of the research.

\section{REFERENCES}

ANDALEEB, S.S. \& CONWAY, C. 2006. Customer satisfaction in the restaurant industry: An examination of the transaction-specific model, The Journal of Services Marketing, 20(1):3-11.

ANSELMSSON, J. 2006. Sources of customer satisfaction with shopping malls: A comparative study of different segments, International Review of Retail, Distribution and Consumer Research, 16(1):115-138.

BABBIE, E. \& MOUTON, J. 2008. The Practice of Social Research. Cape Town: ABC Press.

BARSKY, J. \& NASH, L. 2003. Customer satisfaction: Applying concepts to industry-wide measures, Cornell Hotel and Restaurant Administration Quarterly, 44(5/6):173-183.

BERNHARDT, H.L., DONTHU, N. \& KENNETT, P.A. 2000. A longitudinal analysis of satisfaction and probability, Journal of Business Research, 47(2):161-171.

CHENG, K. 2005. A research on the determinants of consumers' repurchase towards different classes of restaurants in Taiwan, Business Review, 4(2):99-105.

CHI, C.G. \& GURSOY, D. 2009. Employee satisfaction, customer satisfaction, and financial performance: An empirical analysis, International Journal of Hospitality Management, 28(2):245-253.

CHOW, I.H-S., LAU, V.P., LO, T.W-C., SHA, Z. \& YUN, H. 2007. Service quality in restaurant operations in China: Decision- or experiential-oriented perspectives, International Journal of Hospitality Management, 26(3):698-710.

CHUNG, B. \& HOFFMANN, K.D. 1998. Critical incidents: Service failures that matter most, Cornell Hotel and Restaurant Administration Quarterly, 39(3):66-71.

DE NISCO, A. \& NAPOLITANO, M.R. 2006. Entertainment orientation of Italian shopping centres: Antecedents and performance, Managing Service Quality, 16(2):145-166.

DUTTA, K., VENKATESH, U. \& PARSA, H.G. 2007. Service failure and recovery strategies in the restaurant sector: An Indo-US comparative study, International Journal of Contemporary Hospitality Management, 19(5):351-363. 
ENZ, C.A. 2004. Issues of concern for restaurant owners and managers, Cornell Hotel and Restaurant Administration Quarterly, 45(4):315-332.

FRAZÃO, E., MAEDE, B. \& REGMI, A. 2008. Converging patterns in global food consumption and food delivery systems, Amber Waves, 6(1):22-29.

GANESH, J., ARNOLD, M.J. \& REYNOLDS, K.E. 2000. Understanding the customer base of service providers: An examination of the differences between switchers and stayers, Journal of Marketing, 64(3):65-87.

GUPTA, S., MCLAUGHLIN, S.G. \& GOMEZ, M. 2007. Guest satisfaction and restaurant performance, Cornell Hotel and Restaurant Administration Quarterly, 48(3):284-298.

HAN, H., BACK, K.J. \& BARRETT, B. 2009. Influencing factors on restaurant customers' revisit intention: The roles of emotions and switching barriers, International Journal of Hospitality Management, 19(8/9):563-572.

HU, M.L.M. 2009. Developing a core competency model of innovative culinary development, International Journal of Hospitality Management. [Online]. Available from: http://dx.doi:10.1016/j.ijhm.2009.10.024. Retrieved 12/03/2010.

IGLESIAS, M.P. \& GUILLÉN, M.J. 2004. Perceived quality and price: Their impact on the satisfaction of restaurant customers, International Journal of Contemporary Hospitality Management, 16(6):373-379.

JENSEN, Ø. \& HANSEN, K.V. 2007. Consumer values among restaurant customers, Hospitality Management, 26(3):603-622.

JOHNSON, B. \& CHRISTENSEN, L.B. 2004. Educational research: Quantitative, qualitative, and mixed approaches. $2^{\text {nd }}$ edition. Boston, MA: Pearson Education Inc.

KIVELA, J., INBAKARAN, R. \& REECE, J. 1999a. Consumer research in the restaurant environment, Part 1: A conceptual model of dining satisfaction and return patronage, International Journal of Contemporary Hospitality Management, 11(5):205-222.

KIVELA, J., INBAKARAN, R. \& REECE, J. 2000. Consumer research in the restaurant environment, Part 3: Analysis, findings and conclusions, International Journal of Contemporary Hospitality Management, 12(1):13-30.

KIVELA, J., REECE, J. \& INBAKARAN, R. 1999b. Consumer research in the restaurant environment, Part 2: Research design and analytical methods, International Journal of Contemporary Hospitality Management, 11(6):269-286.

LADHARI, R., BRUN, I. \& MORALES, M. 2008. Determinants of dining satisfaction and post-dining behavioural intentions, International Journal of Hospitality Management, 27(4):563-573.

LEEDY, P.D. \& ORMROD, J.E. 2005. Practical research: Planning and design. $8^{\text {th }}$ edition. Upper Saddle River: Prentice-Hall Inc.

LIU, Y. \& JANG, S.C. 2009. The effects of dining atmospherics: An extended Mehrabian-Russell model, International Journal of Hospitality Management, 28(4):494-503.

LOTZ, S.L., EASTLICK, M.A., MISHRA, A. \& SHIM, S. 2010. Understanding patrons' participation in activities at entertainment malls: A study in flow, International Journal of Retail \& Distribution Management 38(6):402-422. 


\section{H. J. Moolman}

Restaurant customer satisfaction and return patronage in a Bloemfontein shopping mall

MCMILLAN, J.H. \& SCHUMACHER, S. 2006. Research in education. $6^{\text {th }}$ edition. New York: Pearson. MOSCHIS. G., CURASI, C.F. \& BELLENGER, D. 2003. Restaurant-selection preferences of mature consumers, Cornell Hotel and Restaurant Administration Quarterly, 44(4):51-60.

MUELLER, R.D., PALMER, A., MACK, R. \& MCMULLAN, R. 2003. Service in the restaurant industry: An American and Irish comparison of service failures and recovery strategies, International Journal of Hospitality Management, 22(4):395-418.

NAMASIVAYAM, K. \& DENIZCI, B. 2006. Human capital in service organisations: Identifying value drivers, Journal of Intellectual Capital, 7(3):381-393.

NAMKUNG, Y. \& JANG, S-C. 2008. Are highly satisfied restaurant customers really different? A quality perception perspective, International Journal of Contemporary Hospitality Management, 20(2):142-155.

NATIONAL RESTAURANT ASSOCIATION. 2010. Restaurant industry facts sheet. [Online]. Available from: http://www.restaurant.org. Retrieved 12/03/2010.

O'NEILL, M. \& PALMER, A. 2001. Survey timing and consumer perceptions of service quality: An overview of empirical evidence, Managing Service Quality, 11(3):182-189.

PARASURAMAN, A., ZEITHAML, V.A. \& BERRY, L.L. 1988. A SERVQUAL: A multi-item scale for measuring customer perceptions of service quality, Journal of Retailing, 64(Spring):12-40.

PARSA, H.G., SELF, J.T, NJITE, D. \& KING, T. 2005. Why restaurants fail, Cornell Hotel and Restaurant Administration Quarterly, 46(3):304-323.

PIETERSEN, J. \& MAREE, K. 2007. Standardisation of a questionnaire. In Maree, K. (Ed.). First Steps in Research. Pretoria: Van Schaik Publishers.

PITT, M. \& MUSA, Z.N. 2009. Towards defining shopping centres and their management systems, Journal of Retail \& Leisure Property, 8(1):39-55.

QUAN, S. \& WANG, N. 2004. Towards a structural model of the tourist experience: An illustration from food experiences in tourism, Tourism Management, 25(3):297-305.

RESTAURANT \& CATERING AUSTRALIA. 2009. Restaurant industry snapshot. [Online]. Available from: http://www.restaurantandcaterer.asn.au. Retrieved 12/03/2010.

REYNOLDS, D. \& BIEL, D. 2007. Incorporating satisfaction measures into a restaurant productivity index, Hospitality Management, 26(2):352-361.

RSA NDT (REPUBLIC OF SOUTH AFRICA NATIONAL DEPARTMENT OF TOURISM). 2011. National Tourism Sector Strategy. Pretoria: Department of Tourism.

SKOGLAND, I. \& SIGUAW, J.A. 2004. Are your satisfied customers loyal?, Cornell Hotel and Restaurant Administration Quarterly, 45(3):221-231.

SÖDERLUND, M. \& ÖHMAN, N. 2005. Assessing behavior before it becomes behavior: An examination of the role of intentions as a link between satisfaction and repatronizing behavior, International Journal of Service Industry Management, 16(2):169-185.

SORIANO, R.D. 2002. Customers' expectations factors in restaurants: The situation in Spain, International Journal of Quality and Reliability Management, 19(8-9):1055-1067. 
SSA (STATISTICS SOUTH AFRICA). 2007. Food and Beverage Industry, 2007. Pretoria: Statistics South Africa.

SSA (STATISTICS SOUTH AFRICA). 2009. Draft Tourism Satellite Account, 2005. Pretoria: Statistics South Africa.

SSA (STATISTICS SOUTH AFRICA). 2010. Food and Beverages, September 2010. Pretoria: Statistics South Africa.

SOUTH AFRICAN TOURISM. 2010. Shopping malls in South Africa. [Online]. Available from: http://www.southafrica.net/sat/content/en/us/. Retrieved 15/12/2010.

STEVENS, P., KNUTSON, B. \& PATTON, M. 1995. DINESERV: A tool for measuring service quality in restaurant, Cornell Hotel and Restaurant Administration Quarterly, 36(2):56-60.

STRUWIG, F.W. \& STEAD, G.B. (2001). Planning, designing and reporting research. Cape Town: Pearson Education South Africa.

SULEK, J.M. \& HENSLEY, R.L. 2004. The relative importance of food, atmosphere, and fairness of wait: The case of a full-service restaurant, Cornell Hotel and Restaurant Administration Quarterly, 45(3):235247.

SUSSKIND, A.M. 2002. I told you so! Restaurant customers' word-of-mouth communication patterns, Cornell Hotel and Restaurant Administration Quarterly, 43(2):75-85.

SUSSKIND, A.M., KACMAR, K.M. \& BORCHGREVINK, C.P. 2007. How organizational standards and coworker support improve restaurant service, Cornell Hotel and Restaurant Administration Quarterly, 48(4):370-379.

THETA (TOURISM, HOSPITALITY AND SPORT EDUCATION AND TRAINING AUTHORITY). 2004. THETA Sector Skills Plan 2005 -2009. Sandton: Tourism, Hospitality and Sport Education and Training Authority.

THETA (TOURISM, HOSPITALITY AND SPORT EDUCATION AND TRAINING AUTHORITY). 2007. Tourism and Sport Skills Audit. Sandton: Tourism, Hospitality and Sport Education and Training Authority.

VINK, N., KIRSTEN, J.F. \& WOERMANN, C. 2004. South Africa's Consumer Price Index for Food (CPIF): A comparative historical view, Agrekon, 43(2):217-227.

WTTC (WORLD TRAVEL \& TOURISM COUNCIL). Travel and Tourism Economic Impact Summary. 2010. [Online]. Available from: http://www.wttc.org/bin/pdf/temp/2010 exec summary final.htm. Retrieved $15 / 08 / 2011$.

WU, C.H-J. \& LIANG, R-D. 2009. Effect of experiential value on customer satisfaction with service encounters in luxury-hotel restaurants, International Journal of Hospitality Management, 28(4):563-593.

YÜKSEL, A. \& YÜKSEL, F. 2004. Measurement of tourist satisfaction with restaurant services: a segmentbased approach, Journal of Vocation Marketing, 9(1):52-68. 